\title{
Effect of Azolla feeding on the growth, feed conversion ratio, blood biochemical attributes and immune competence traits of growing turkeys
}

\author{
Mayank Shukla ${ }^{1}$, Amitav Bhattacharyya ${ }^{1}$, Pankaj Kumar Shukla ${ }^{1}$, Debashis Roy ${ }^{2}$, Brijesh Yadav ${ }^{3}$ and Rajneesh Sirohi ${ }^{4}$
}

1. Department of Poultry Science, College of Veterinary Science and Animal Husbandry, Mathura, Uttar Pradesh, India;

2. Department of Animal Nutrition, College of Veterinary Science and Animal Husbandry, Mathura, Uttar Pradesh, India;

3. Department of Veterinary Physiology, College of Veterinary Science and Animal Husbandry, Mathura, Uttar Pradesh,

India; 4. Livestock Production and Management, College of Veterinary Science and Animal Husbandry, Mathura, Uttar Pradesh, India.

Corresponding author: Amitav Bhattacharyya, e-mail: amitav16@rediffmail.com

Co-authors: MS: drmayankshukla1213@gmail.com, PKS: pksmathura@yahoo.co.in, DR: debashis2k4@gmail.com, BY: drbrijvet@gmail.com, RS: vetsirohi@rediffmail.com

Received: 31-10-2017, Accepted: 03-03-2018, Published online: 11-04-2018

doi: 10.14202/vetworld.2018.459-463 How to cite this article: Shukla M, Bhattacharyya A, Shukla PK, Roy D, Yadav B, Sirohi R (2018) Effect of Azolla feeding on the growth, feed conversion ratio, blood biochemical attributes and immune competence traits of growing turkeys, Veterinary World, 11(4): 459-463.

\begin{abstract}
Background and Aim: In the recent past, few studies have been carried out in chicken to assess the effect of Azolla meal and raw Azolla feeding on the performance of chicken. If turkeys effectively use unconventional feedstuffs like Azolla without reducing the performance, it will increase the profitability of turkey business. Hence, a study was carried out to evaluate the effect of dried Azolla pinnata vis-a-vis raw Azolla as choice feeding on the growth, feed conversion ratio (FCR), blood biochemical attributes, and immune competence traits of growing turkeys under intensive system.

Materials and Methods: A total of 72, 8-week-old grower turkey poults of black variety were randomly distributed into three dietary treatments having three replicates each with eight birds. The birds of the control group (T1) were fed a basal $\operatorname{diet}(\mathrm{CP}-19.71 \%$ and $\mathrm{ME}-2789.79 \mathrm{Kcal} / \mathrm{kg}$ ), while the other group (T2) and choice-feeding group (T3) were fed 5\% of basal diet replaced by dry Azolla powder on DM basis and ad libitum Azolla along with basal diet, respectively.

Results: There was no significant difference among the different groups in the average weekly weight gain during the entire experiment. FCR was significantly better $(\mathrm{p}<0.05)$ in the choice-feeding group compared to the other two experimental groups during 8-16 weeks of age. There was no significant difference among the treatment groups in any of the blood biochemical indices except plasma uric acid, which was significantly decreased $(\mathrm{p}<0.01)$ in T2 compared to T1 at 16 weeks of age. HA and IgM response to $1 \%$ sheep red blood cells (log2 titer) were numerically better in $\mathrm{T} 2$ and $\mathrm{T} 3$ compared to the T1.
\end{abstract}

Conclusion: Thus, it may be inferred that choice feeding with Azolla, and basal diet may improve FCR without any adverse effect on blood biochemical attributes and immune competence traits.

Keywords: Azolla, biochemical attributes, body weight, immunity, turkeys.

\section{Introduction}

Research on the utilization of green forages and feed has increased considerably during the past few years. It has been seen that turkeys consume more vegetables (green feeds) than do poultry. Hence, feed factor is quite significant for turkeys under the intensive system, as they have no direct contact with plant feeds, especially green feeds. Besides, the phenomenal increase in poultry production has resulted in competition with the conventional human food ingredients leading to a shortage and increased the cost of conventional feed ingredients [1]. Since the cost of the feed

Copyright: Shukla, et al. Open Access. This article is distributed under the terms of the Creative Commons Attribution 4.0 International License (http://creativecommons.org/licenses/by/4.0/), which permits unrestricted use, distribution, and reproduction in any medium, provided you give appropriate credit to the original author(s) and the source, provide a link to the Creative Commons license, and indicate if changes were made. The Creative Commons Public Domain Dedication waiver (http://creativecommons.org/ publicdomain/zero/1.0/) applies to the data made available in this article, unless otherwise stated. accounts for nearly $75 \%$ of the total cost of turkey production, the substitution of conventional feedstuffs by unconventional feedstuff will lead to a reduction in the cost of turkey feed, and hence, increase the margin of profit in turkey business.

Azolla is a small aquatic fern that flows on the water surface. The use of Azolla as a drug, reclaiming saline soils [2], and bioremediation $[3,4]$ has also been investigated. Few studies have been carried out in chicken to assess the effect of Azolla meal and raw Azolla feeding on the performance of chickens [5-7]. If turkeys effectively use unconventional feedstuffs like Azolla without reducing the performance, it will increase the profitability of turkey business.

It has already been established that choice-feeding system may play a pivotal role in reducing the feed cost of laying hens and turkeys in developing countries [8]. The basic principle behind free choice feeding is that individual birds can select from the various feed ingredients and thus get a chance to compose 
their diet according to their actual requirement and capacity of production.

Hence, the present study was carried out to evaluate the effect of dried Azolla pinnata meal vis-a-vis raw Azolla as choice feeding on the body weight, feed conversion ratio (FCR), blood biochemical attributes, and immune competence traits of growing turkeys under intensive system.

\section{Materials and Methods}

\section{Ethical approval}

Experiment was carried out in accordance with the guidelines laid down by the Institute Animal Ethics Committee for the use of poultry birds.

\section{Preparation of Azolla meal}

Raw A. pinnata was procured from "Azolla Demonstration Unit" of the University. Raw Azolla was sundried in a clean and dust-free environment to obtain fine powder. The powder formed was packed in an airtight container.

\section{Experimental design, housing, feeding, and management}

A total of 72, 8-week-old black variety of turkey poults were divided into three treatment groups, comprising three replicates and eight turkey poults in each replicate. The chicks were wing banded, weighed individually, and distributed randomly on uniform body weight basis in the treatment groups. The birds were housed in deep litter system. Water was offered ad libitum. The birds of the control group (T1) were fed a basal diet (19.71\% CP and 2789.79 Kcal ME/kg), while the other group (T2) and choice-feeding group (T3) were fed 5\% of basal diet replaced by dry Azolla powder on DM basis and ad libitum Azolla along with the basal diet, respectively. Representative samples of Azolla meal, T1 and T2, were analyzed for their nutrient composition, namely, dry matter, ether extract, crude protein, total ash, crude fiber, calcium, and phosphorous (Table-1).

\section{Body weight gain and FCR}

Weekly body weight gain was recorded, and thereafter, FCR was determined for different phases of growth (8-12 weeks, 12-16 weeks, and 8-16 weeks) on the basis of feed consumption and on the basis of total dry matter intake (feed and Azolla).

\section{Biochemical attributes}

After 16 weeks of age, blood was collected from the wing vein of 9 birds of each group (3 birds from each replicate) with the help of heparinized and non-heparinized syringes and poured into sterile tubes. The blood samples were centrifuged for the 10-15 min at $2500 \mathrm{rpm}$. Plasma and serum were separated and stored in refrigerator $\left(-20^{\circ} \mathrm{C}\right)$ until analyzed. Plasma cholesterol, high-density lipoprotein cholesterol, protein, uric acid, glutamate oxaloacetate transaminase or aspartate aminotransferase, glutamate pyruvic transaminase or alanine aminotransferase, and alkaline phosphatase were determined using commercial kits (Span Cogent Diagnostics product, India), according to the manufacturer's instructions.

\section{ELISA}

Reactive oxygen species level in plasma was determined by ELISA using the method suggested by Brambilla et al. [9] with slight modification. $200 \mu \mathrm{L}$ acetate buffer $(0.1 \mathrm{M} \mathrm{pH} 4.8)$ was dispensed in 96-well plates (Nunc-Immunoplates, Nalge Nunc Italia, Rome, Italy) by a multichannel pipette. An aliquot of $5 \mu \mathrm{L}$ for each serum, previously diluted $1: 10 \mathrm{v} / \mathrm{v}$, was then added by micropipette. Each sample was tested in duplicate. The plate was shaken gently for $1 \mathrm{~min}$ on a thermo-shaker (Gerhardt, Bonn, Germany). Then, 5 $\mu \mathrm{L}$ of a chromogen solution containing $0.37 \mathrm{M}$ of $\mathrm{N}$, $\mathrm{N}$-diethyl-para-phenylenediamine as substrate was added to each well. Plates were incubated for $75 \mathrm{~min}$ at $+37^{\circ} \mathrm{C}$ in the dark with gentle shaking. A standard curve was prepared using different concentrations of $\mathrm{H}_{2} \mathrm{O}_{2}$ in place of serum. Absorbance was read on a microplate reader (Bio-Rad ELISA reader) at $495 \mathrm{~nm}$ and values after background subtraction plotted against $\mathrm{H}_{2} \mathrm{O}_{2}$ concentrations. Serum superoxide dismutase (SOD) activity was measured using the method as described by Madesh and Balasubramanian [10] with some modifications. In the microtiter plate method, the assay mixture in a total volume of $300 \mu \mathrm{L}$ per well consisted of $120 \mu \mathrm{L}$ PBS, $10 \mu \mathrm{L}$ serum sample, $5 \mu \mathrm{L}$ of $1.25 \mathrm{mM}$ 3-(4,5-dimethyl-thiazol-2-yl) 2,5-diphenyl tetrazolium bromide (MTT), and $15 \mu \mathrm{L}$ of freshly prepared $1 \mathrm{mM}$ pyrogallol solution to be added at the end. Sample was replaced with PBS in the blank. After an incubation period of $15 \mathrm{~min}, 150 \mu \mathrm{L}$ of dimethyl sulfoxide was added and absorbance was taken in ELISA reader at $570 \mathrm{~nm}$. The percentage inhibition by the presence of SOD was calculated from the reduction of the MTT color formation as compared to the MTT formazan formed in the absence of SOD which was taken as $100 \%$.

\section{Immune competence traits}

After 16 weeks of age, general immune response was studied by taking 9 birds from each treatment group ( 3 birds from each replicate) and measuring important immunocompetence traits such as antibody response $\left(\log _{2}\right.$ titer) to $1 \%$ sheep red blood cells

Table-1: Proximate analysis of Azolla meal and turkey feed on dry matter basis.

\begin{tabular}{lccccccc}
\hline Category & $\begin{array}{c}\text { Dry matter } \\
(\mathbf{\%})\end{array}$ & $\begin{array}{c}\text { Total Ash } \\
\mathbf{( \% )}\end{array}$ & $\begin{array}{c}\text { Ether extract } \\
\mathbf{( \% )}\end{array}$ & $\begin{array}{c}\text { Calcium } \\
\mathbf{( \% )}\end{array}$ & $\begin{array}{c}\text { Phosphorous } \\
\mathbf{( \% )}\end{array}$ & $\begin{array}{c}\text { Crude protein } \\
(\mathbf{\%})\end{array}$ & $\begin{array}{c}\text { Crude fiber } \\
(\%)\end{array}$ \\
\hline Azolla meal & 98.8 & 21.67 & 3.15 & 1.11 & 0.59 & 25.64 & 17.29 \\
T1 & 89.96 & 3.29 & 4.31 & 0.89 & 0.52 & 19.30 & 3.91 \\
T2 & 85.95 & 3.85 & 4.25 & 1.41 & 0.79 & 19.67 & 4.58 \\
\hline
\end{tabular}


(SRBC) [11,12], 2-mercaptoethanol resistant antibodies (MER or IgG) and mercaptoethanol-sensitive antibodies (MES or IgM) against SRBC [13], and cell-mediated immune response to phytohemagglutinin-P (PHA-P) [14].

\section{Statistical analysis}

Data were subjected to one-way analysis of variance in a completely randomized design [15]. Significant differences among treatment means were calculated as per Duncan's multiple range test [16]. Differences among treatments were considered to be statistically significant when $\mathrm{p} \leq 0.05$.

\section{Results}

\section{Body weight gain}

There was no significant difference in body weight gain among the treatment groups during 8-16 weeks of age (Table-2).

FCR

FCR was significantly better $(p<0.01)$ in the choice-feeding group compared to the other two experimental groups during 8-12 weeks of age (Table-3). Further, FCR was numerically better in the choice-feeding group compared to the other two experimental groups during 12-16 weeks of age. In addition, overall FCR was significantly better $(p<0.05)$ in the choice-feeding group compared to the other two experimental groups during 8-16 weeks of age. However, there was no significant difference observed in the overall FCR on the basis of total dry matter intake among the different treatment groups during 8-16 weeks of age (Table-3).

\section{Blood biochemical attributes}

There was no significant difference among the treatment groups in any of the blood biochemical indices except plasma uric acid at 16 weeks of age (Table-4). Plasma uric acid was significantly decreased $(p<0.01)$ in $T 2$ compared to T1. However, there was no significant difference in the plasma uric acid between $\mathrm{T} 2$ and $\mathrm{T} 3$.

\section{Immune response}

$\mathrm{HA}$ and IgM response to $1 \%$ SRBC ( $\log _{2}$ titer) was numerically better in both the Azolla-fed groups compared to the control group (Table-5). Further, the $\mathrm{HA}$ and IgM response to $1 \%$ SRBC was comparatively better in the choice-feeding group compared to the 5\% Azolla-fed group. However, IgG response was significantly higher $(\mathrm{p}<0.01)$ in the control group compared to the other two Azolla-fed groups.

No significant difference was found in response to PHA-P among the treatment groups (Table-5). However, cell-mediated immune response to PHA-P was numerically better in both the Azolla-fed groups compared to the control group.

\section{Discussion}

\section{Chemical composition of Azolla}

The proximate composition of Azolla was in concurrence with the values obtained in other studies [17-19]. The percent ether extract on dry matter basis of Azolla meal was 3.15, which was in agreement with the values 3.70 and 3.62 as reported by Balaji et al. [17] and Ara et al. [19], respectively. Similarly, the percentage of protein on dry matter basis of Azolla meal was 25.64, which was in concurrence with the values 24.5 and 26.02 as reported by Balaji et al. [17] and Parthasarathy et al. [18], respectively. Further, the percentage of total ash on dry matter basis of Azolla meal was 21.67, which was in concurrence with 18.1 reported by Ara et al. [19]. Similarly, the

Table-2: Effect of Azolla feeding on the average weekly body weight gain ( $\mathrm{g}$ ) of grower turkeys during 8-16 weeks of age.

\begin{tabular}{lccccc}
\hline Weeks & Control & $\mathbf{5 \%}$ Azolla & Choice feeding & Pooled SEM & Significant level \\
\hline 9 & 179.50 & 167.92 & 181.79 & 4.41 & NS \\
10 & 160.17 & 170.00 & 181.41 & 6.24 & NS \\
11 & 183.13 & 160.34 & 137.50 & 8.49 & NS \\
12 & 150.46 & 176.13 & 184.34 & 9.49 & NS \\
13 & 208.46 & 225.63 & 218.92 & 6.54 & NS \\
14 & 218.08 & 180.67 & 187.46 & 9.89 & NS \\
15 & 206.26 & 195.58 & 189.96 & 11.97 & NS \\
16 & 189.51 & 234.75 & 235.50 & & \\
\hline
\end{tabular}

NS=Non-significant $(p>0.05)$ SEM $=$ Standard error of means

Table-3: Effect of Azolla feeding on the FCR (only feed) and FCR on total DM intake basis (feed and Azolla) of grower turkey during $8-12,12-16$, and 8-16 weeks of age.

\begin{tabular}{|c|c|c|c|c|c|c|c|c|c|c|}
\hline \multirow{2}{*}{$\begin{array}{l}\text { Phases of } \\
\text { growth } \\
\text { (week) }\end{array}$} & \multicolumn{5}{|c|}{ FCR (only feed) } & \multicolumn{5}{|c|}{ FCR on total DM intake basis (feed and Azolla) } \\
\hline & Control & $\begin{array}{c}5 \% \\
\text { Azolla }\end{array}$ & $\begin{array}{l}\text { Choice } \\
\text { feeding }\end{array}$ & $\begin{array}{l}\text { Pooled } \\
\text { SEM }\end{array}$ & $\begin{array}{l}\text { Sig. } \\
\text { level }\end{array}$ & Control & $\begin{array}{c}\mathbf{5 \%} \\
\text { Azolla }\end{array}$ & $\begin{array}{l}\text { Choice } \\
\text { feeding }\end{array}$ & $\begin{array}{l}\text { Pooled } \\
\text { SEM }\end{array}$ & $\begin{array}{l}\text { Sig. } \\
\text { level }\end{array}$ \\
\hline $8-12$ & $2.86^{a}$ & $2.64^{a}$ & $2.34^{b}$ & 0.08 & $p<0.01$ & 2.57 & 2.37 & 2.60 & 0.05 & NS \\
\hline $12-16$ & 3.51 & 3.62 & 3.24 & 0.09 & NS & 3.16 & 3.26 & 3.28 & 0.07 & NS \\
\hline $8-16$ & $3.21^{\mathrm{a}}$ & $3.18^{\mathrm{a}}$ & $2.83^{b}$ & 0.08 & $\mathrm{P}<0.01$ & 2.89 & 2.86 & 2.97 & 0.04 & NS \\
\hline
\end{tabular}

Means bearing different superscripts within a column differ significantly $(p<0.05)$. NS=Non-significant $(p>0.05)$, $\mathrm{SEM}=$ Standard error of means, $\mathrm{FCR}=$ Feed conversion ratio 
Table-4: Effect of Azolla feeding on blood biochemicals (protein, uric acid, cholesterol, AST, ALT, and ALP) of grower turkeys at 16 weeks of age.

\begin{tabular}{lccccc}
\hline Parameters & Control & $\mathbf{5 \%}$ Azolla & Choice feeding & Pooled SEM & Significant level \\
\hline Protein $(\mathrm{g} / \mathrm{dl})$ & 2.73 & 2.66 & 3.12 & 0.15 & $\mathrm{NS}$ \\
Uric acid $(\mathrm{mg} / \mathrm{dL})$ & $6.28^{\mathrm{a}}$ & $5.42^{\mathrm{b}}$ & $5.87^{\mathrm{ab}}$ & 0.12 & $\mathrm{p}<0.01$ \\
Cholesterol $(\mathrm{mg} / \mathrm{dL})$ & 126.51 & 130.43 & 117.95 & 3.49 & $\mathrm{NS}$ \\
AST (IU/L) & 3.31 & 5.08 & 2.65 & 0.65 & $\mathrm{NS}$ \\
ALT (IU/L) & 7.74 & 5.30 & 5.30 & 0.74 & $\mathrm{NS}$ \\
ALP (IU/L) & 219.84 & 151.36 & 250.52 & 25.50 & $\mathrm{NS}$ \\
HDL (mg/dL) & 55.74 & 54.14 & 54.20 & 2.13 & $\mathrm{NS}$ \\
SOD (units/mL) & 216.56 & 218.01 & 219.59 & 2.11 & $\mathrm{NS}$ \\
ROS (mg $\mathrm{H}_{2} \mathrm{O}_{2}$ equivalents/mL) & 40.85 & 39.45 & 39.83 & 0.35 & $\mathrm{NS}$ \\
\hline
\end{tabular}

Means bearing different superscripts within a column differ significantly $(p<0.05)$. NS=Non-significant $(p>0.05)$

$\mathrm{SEM}=$ Standard error of means, $\mathrm{FCR}=$ Feed conversion ratio

Table-5: Effect of Azolla feeding on the humoral immune responses (antibody titer [log 2] values) to $1 \%$ SRBC of values and cell-mediated immune response (response to PHA-P) (foot web index) of grower turkey at 16 weeks of age.

\begin{tabular}{lccccc}
\hline Parameters & Control & 5\% Azolla & Choice feeding & Pooled SEM & Significant level \\
\hline HA & 7.34 & 7.71 & 8.63 & 0.29 & $\mathrm{NS}$ \\
IgG & $1.50^{\mathrm{a}}$ & $1.00^{\mathrm{b}}$ & $1.00^{\mathrm{b}}$ & 0.08 & $\mathrm{p}<0.01$ \\
IgM & 5.83 & 6.71 & 7.63 & 0.32 & $\mathrm{NS}$ \\
Foot web index & 0.61 & 0.76 & 0.78 & 0.05 & $\mathrm{NS}$ \\
\hline
\end{tabular}

Means bearing different superscripts within a column differ significantly $(p<0.05)$. NS=Non-significant $(p>0.05)$, $\mathrm{SEM}=$ Standard error of means

percentage of crude fiber on dry matter basis of Azolla meal was 17.29 and was in agreement with the values 14.3 and 14.9 reported by Ara et al. [19] and Balaji et al. [17], respectively.

\section{Growth performance}

In our study, there was no significant difference in the body weight gain among the treatment groups. Similarly, Parthasarathy et al. [18] reported no significant difference in body weight gain of broilers on basal and 5\% Azolla diets. Balaji et al. [17] also noted that inclusion of Azolla up to $4.5 \%$ in rations did not have any influence on body weight gain in broiler chicken. These observations suggested that green Azolla, when fed ad libitum with the basal diet or replaced $5 \%$ of the basal diet on DM basis, had no adverse effect on body weight gain. Further, Naghshi et al. [20] reported that chicken fed 5\% Azolla powder had significantly $(\mathrm{p}<0.01)$ better daily weight gain compared to the basal diet.

In our study, the significantly better $(p<0.01)$ FCR in the choice-feeding group compared to the other two experimental groups during 8-12 weeks of age and 8-16 weeks of age may be attributed to the intrinsic mechanism of the birds to choose the best food for them.

\section{Blood biochemical parameters}

In the present study, values of biochemical parameters are in range as reported in other studies on turkeys [21]. There was no significant difference among the treatment groups in any of the blood biochemical indices except plasma uric acid at 16 weeks of age. Sujatha et al. [7] also noted that there was no significant difference in the serum protein concentration between the control group fed basal diet and
Azolla-based diet in Nicobari fowls. The significantly lower plasma uric acid in the 5\% Azolla group and numerically lower uric acid value in the choice-feeding group compared to the control group may be due to better utilization of protein in these two groups. However, there is a paucity of information on studies carried out in blood biochemical attributes about Azolla-based diets.

\section{Immune response}

There was no significant difference in HA and IgM response to $1 \% \mathrm{SRBC}\left(\log _{2}\right.$ titer) among the treatment groups. However, HA and IgM response to $1 \%$ SRBC ( $\log _{2}$ titer) was numerically better in both the Azolla-fed groups compared to the control group. This is in agreement with the study of Bhattacharyya et al. [5] who also reported that total immunoglobulins and MES $(\operatorname{IgM})$ antibody titer $(\log 2)$ values in response to SRBC were significantly higher $(\mathrm{p}<0.05)$ in the basal diet replaced with dry $A$. pinnata powder at $5.5 \%$ on dry matter basis birds than the control group commercial birds at 6 weeks of age. However, Sujatha et al. [7] noted that there was no significant difference between the mean HI titer and MER titer between the control group and fresh Azolla fed at $200 \mathrm{~g}$ per chick per day from 45 to 60 weeks in Nicobari fowls. Further, the HA and IgM response to $1 \%$ SRBC was comparatively better in the choice-feeding group compared to the 5\% Azolla-fed group. This may be due to the reason that growing turkeys are good foragers and there is an intrinsic mechanism of the birds to choose the best food for them resulting in numerically better immunity.

The results of our present study revealed that there was no adverse effect of Azolla on the immune system of turkeys. Our results are in conformity with 
Bhattacharyya et al. [22] who also reported that antibody response to SRBC was not affected by green berseem replacement in the conventional ration of turkeys.

There was no significant difference in the cell-mediated response to PHA-P among the treatment groups. This is in agreement with the study of Sujatha et al. [7] who also noted that there was no significant difference in the cell-mediated immune response between the Azolla-fed group and the control group. However, cell-mediated immune response to PHA-P was numerically better in both the Azolla-fed groups compared to the control group. This may be due to the reason that turkeys are good foragers and access to green feeds plays an important role in determining the health and immunity of turkeys along with an intrinsic mechanism of the birds to choose the best food for them, resulting in better immunity. Bhattacharyya et al. [22] also reported that foot web index of grower turkeys was numerically higher in the choice-feeding group having access to ad libitum basal diet and green berseem. In another study, Bhattacharyya et al. [5] reported that foot index was significantly $(\mathrm{P}<0.05)$ higher in the basal diet replaced with dry A. pinnata powder at $5.5 \%$ on dry matter basis group birds than the control group commercial birds at 6 weeks of age.

\section{Conclusion}

It may be inferred that choice feeding with Azolla and basal diet may improve FCR without any adverse effect on blood biochemical attributes and immune competence traits.

\section{Authors' Contributions}

PKS, AB, and DR designed the study. MS conducted the experimental work and RS assisted during the experiment. $\mathrm{AB}$ and $\mathrm{BY}$ drafted the manuscript and corrected it. All authors read and approved the final manuscript.

\section{Acknowledgments}

The authors are grateful to Vice Chancellor, U.P. Pandit Deen Dayal Upadhyaya Pashu-chikitsa VigyanViswavidyalaya Evam Go-Anusandhan Sansthan, Mathura, for providing the necessary facilities and funds for carrying out this study (University Grant to Department of Poultry Science, Dated 23/05/14, Financial Year 2014-15).

\section{Competing Interests} interests.

The authors declare that they have no competing

\section{References}

1. Council for Agricultural Science and Technology (CAST). (2013) Animal Feed vs. Human Food: Challenges and Opportunities in Sustaining Animal Agriculture toward 2050. Issue Paper, 53. CAST, Ames, Iowa.

2. Raja, W., Rathaur, P., Suchit, A.J. and Ramteke, P.R. (2012) Azolla: An aquatic pteridophyte with great potential. Int. J.
Res. Biol. Sci., 2: 68-72.

3. Sood, A., Uniyal, P.L., Prasanna, R. and Ahluwalia, A.S. (2012) Phytoremediation potential of aquatic macrophyte, Azolla. Ambio., 41: 122-137.

4. Yadav, R.K.G., Abraham, Y., Singh, V. and Singh, P.K. (2014) Advancements in the utilization of Azolla anabaena system in relation to sustainable agricultural practices. Proc. Indian Natl. Sci. Acad., 80: 301-316.

5. Bhattacharyya, A., Shukla, P.K., Roy, D. and Shukla, M. (2016) Effect of Azolla supplementation on growth, immunocompetence and carcass characteristics of commercial broilers. J. Anim. Res., 6: 941-945.

6. Mishra, D.B., Roy, D., Kumar, V., Bhattacharyya, A., Kumar, M., Kushwaha, R. and Vaswani, S. (2016) Effect of feeding different levels of Azolla pinnata on blood biochemicals, hematology and immunocompetence traits of Chabro chicken. Vet. World, 9: 192-198.

7. Sujatha, T., Udhayakumari, D., Kundu, A., Jeyakumar, S., Sundar, J. and Kundu, M.S. (2013) Utilization of raw Azolla as a natural feed additive for sustainable production in Nicobari fowl. Anim. Sci. Reporter, 7: 146-152.

8. Bhattacharyya, A., Majumdar, S., Bhanja, S.K. and Singh, R.P. (2006) Effect of feeding green berseem on growth and carcass characteristics of growing Turkey poults. Indian J. Poult. Sci., 41: 58-63.

9. Brambilla, G., Fiori, M. and Archetti, L.I. (2001) Evaluation of the oxidative stress in growing pigs by microplate assays. J. Vet. Med. A. Physiol. Pathol. Clin. Med., 48: 33-38.

10. Madesh, M. and Balasubramanian, K.A. (1998) Microtiter plate assay for superoxide dismutase using MTT reduction by superoxide. Indian J. Biochem. Biophy. 35: 184-188.

11. Siegel, P.B. and Gross, W.B. (1980) Production and persistency of antibodies in chickens to sheep erythrocytes. 1. Directional selection. Poult. Sci., 59: 1-5.

12. Van der Zijpp, A.J. (1983) The effect of genetic origin, source of antigen and dose of antigen on the immune response of cockerels. Poult. Sci., 62: 205-211.

13. Martin, A., Gross, W.B. and Siegel, P.B. (1989) IgG and $\mathrm{IgM}$ responses in high and low antibody selected lines of chickens. J. Hered., 80: 249-252.

14. Corrier, D.E. and Deloach, J.R. (1990) Evaluation of cell-mediated, cutaneous basophil hypersensitivity in young chickens by interdigital skin test. Poult. Sci., 69: 403-408.

15. Snedecor, G.W. and Cochran, W.G. (1994) Statistical Methods. $8^{\text {th }}$ ed. Oxford and IBH Pub. Co., Kolkata.

16. Duncan, D.B. (1955) Multiple range and F-test. Biometrics, 11: $1-42$.

17. Balaji, K., Jalaludeen, A., Churchil, R.R., Peethambaran, P.A. and Kumar, S.S. (2009) Effect of dietary inclusion of Azolla (Azolla pinnata) on production performance of broiler chicken. Indian J. Poult. Sci., 44: 195-198.

18. Parthasarathy, R., Kadirvel, R. and Kathaperumal, V. (2002) Azolla as a partial replacement for fishmeal in broiler rations. Indian Vet. J., 79: 144-146.

19. Ara, S., Adil, S., Banday, M.T. and Khan, M.A. (2015) Feeding potential of aquatic fern-azolla in broiler chicken ration. J. Poult. Sci. Tech., 3: 15-19.

20. Naghshi, H., Khojasteh, S., Jafari, M. (2014) Investigation the effect of different levels of Azolla (Azolla Pinnata) on performance and carcass characteristics of cob broiler chicks. Int. J. Farming Allied Sci., 3(1): 45-49.

21. Sharma, A., Shukla, P.K., Bhattacharyya, A., Kumar, U., Roy, D., Yadav, B., Prakash, A. (2018) Effect of dietary supplementation of sea buckthorn and giloe leaf meal on the body weight gain, feed conversion ratio, biochemical attributes and meat composition of Turkey poults. Vet. World, 11: 93-98.

22. Bhattacharyya, A., Majumdar, S., Bhanja, S.K., Mandal, A.B. and Agarwal, S.K. (2004) Influence of green berseem on the growth performance and immune response in growing Turkey poults. IPSACON, Palampur, India. p42-43. 